\title{
The Impact of Covid-19 Pandemic on the Forecasting Indonesian Composite Stock Price Index
}

\author{
Mayasir Aziza*, Nurafni Eltivia, Nur Indah Riwajanti \\ Accounting Department \\ State Polytechnic of Malang \\ Malang, Indonesia \\ *mayasiraziza19@gmail.com
}

\begin{abstract}
This study aims to obtain the Composite Stock Price Index's closing price forecast from January to October 2021. This research method uses the single exponential smoothing method. The sample used in this study is the composite stock price index at the closing price for all sectors and all companies on the Indonesia Stock Exchange on a week scale from October 2015 to October 2020. The forecasting results show that the Composite Stock Price Index will have a value expected to return to normal. The period before the Covid-19 pandemic. This study provides forecasting results based only on the combined stock price index data for five periods with Microsoft Excel calculations using predetermined formulas. Forecasting results show that in 2021 the stock price index will reach normal conditions like it was before the Covid-19 pandemic. Investors can use forecasting information on this composite stock index to determine the action of selling or buying shares because the composite price index reflects the performance conditions of all companies listed on the Indonesia Stock Exchange and shows the country's economic needs. Suggestions for further research are to be able to predict the combined price index of each sector.
\end{abstract}

Keywords-forecasting, exponential smoothing, composite stock price index, covid-19 pandemic

\section{INTRODUCTION}

The Covid-19 pandemic has greatly affected all world economic activities including the performance of companies listed on the Indonesia Stock Exchange due to restricted activities as the state's efforts to stop the transmission of covid19 diseases such as lockdown and PSBB. According to information from Bank Indonesia and the Minister of Finance, the Republic of Indonesia illustrates that the Indonesian economy will be able to improve at least in early 2021 [1].

Investing in stocks in the capital market is very attractive because investors can get dividends and capital gains. High return from investment is inseparable from high risk so that forecasting is expected to reduce the uncertainty that occurs and can minimize negative sentiment from investors and potential investors in the capital market and help investors to make the right decisions to take action to sell or buy shares. The composite stock price index is also able to see the current situation in Indonesia and the capital market situation, namely a low composite stock price index indicating that the market is in a weak condition [2].

Investors always pay attention to market conditions in general are showing an increase or decrease. In 2020 the performance of the company and the stock market was unlike the previous period, so there was a significant decrease in the value of the Composite Stock Price Index due to the impact of Covid-19 which limited all operational activities of the company and society [3].

The composite stock price index is a description of the state of the performance results of all companies listed on the Indonesia Stock Exchange and can reflect the state of the Indonesian economy in the capital market [4]. The composite stock price index is an essential factor for investors in deciding to sell or buy shares [1].

Previous research on forecasting the composite stock price index has been carried out using the ARIMA time series modeling method [5]. The difference between this study and previous research is that in this study the calculations were carried out by maximizing the existing facilities in Microsoft Excel using the exponential smoothing method [6,7]

The purpose of this study is to obtain the results of forecasting closing price of the composite stock price index during January to October 2021. This forecasting information is expected to assist investors in determining the best decision for stock investment, namely the decision to buy or maintain or the decision to sell shares appropriately.

\section{LITERATURE REVIEW}

The composite stock price index is an indicator that shows the movement of shares of all issuers listed on the Indonesia Stock Exchange and shows an active or weak market trend. In this study, you will be able to see the movement of the composite stock price index before the Covid 19 pandemic and when it occurred [8].

Forecasting is a method used to estimate future value in order to reduce uncertainty and errors in the analysis of the composite stock price index. It should be noted that the 
principles in the forecasting method only reduce uncertainty and do not eliminate. Short-term forecasting will have higher accuracy [9].

Exponential smoothing is a sophisticated and easy-to-use method. Single exponential smoothing or simple exponential smoothing is a method developed from the moving average way [10]. The exponential smoothing model is appropriate if it is used for forecasting for a short period [11]. Simple exponential smoothing is suitable for data without trends and patterns [12]. In this study, the simple exponential smoothing method is used as a tool to calculate the future composite price forecast index, namely the year 2021 based on the movement of the mixed stock index data for 2015-2020.

\section{METHODS}

This research method uses the single exponential smoothing method to calculate the forecasting value of the combined stock price index in 2021. The formula that can be used to calculate forecasting using the exponential smoothing method is as follows [10].

$$
\mathrm{Ft}+1=\alpha \mathrm{Xt}+(1-\alpha) \mathrm{Ft}-1
$$

Using the exponential smoothing calculation method, the data processed in this study uses composite stock price index data on a week scale in the period October 2015 - October 2020. The composite stock price index data in question is the composite stock price index data at the closing price for the entire sectors and all companies on the Indonesia Stock Exchange. The data used is secondary data obtained from https://finance.yahoo.com. Data processing using Microsoft Excel application with the formula used is as follows:

- To find the moving average value for each period.

$=$ AVERAGE \{composite stock price index score from the first week to the fourth week

- Center moving average.

$=$ AVERAGE \{Value of the first moving average / Value of next moving average

- Seasonality irregularity. This irregularity seasonality shows the original data is below or above the average. The calculation uses the following formula:

$=$ Closing price $/$ center moving average

- Seasonality (to show a repeating pattern). The first thing to do is to create a table for the average that occurs in each of the first weeks to the fourth week using the following formula:

$=$ AVERAGE $\{$ data for the first week of the first month, in the second week of the first month, and so on until the entire period of data taken\}
Based on the table of average data for the first week to week four, you can find the Seasonality value with a formula:

$=$ VLOOKUP \{period one, two, three, or four, seasonality table, 2$\}$

- Diseasonality. The function of diseasonality is to show:

$=$ closing price $/ \mathrm{St}$

- Trend. The formula used to calculate the trend is:

$=$ Intercept coefficient $+\mathrm{t}$ coefficient $\mathrm{X} \mathrm{t}$

- Forecast value

$=\mathrm{St} *$ trend

\section{RESULTS AND DISCUSSION}

Figure 1 results from calculations using an excel formula, which shows the original data graph of the composite stock price index, a central moving average chart, and a diagram for forecasting the composite stock price index.

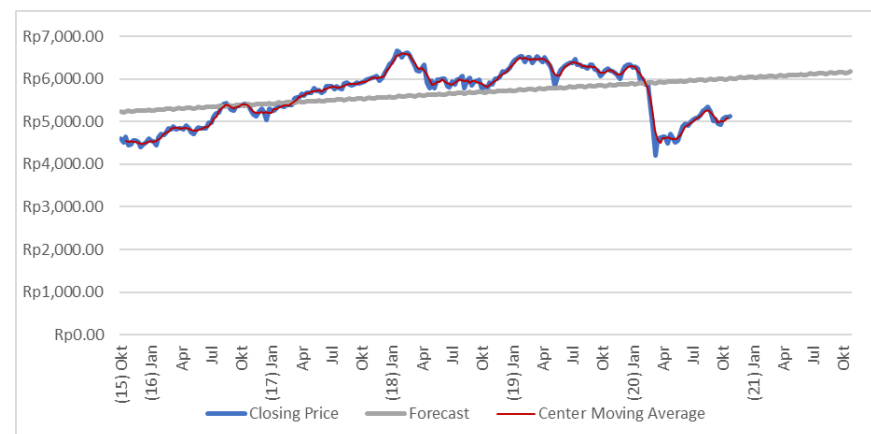

Fig. 1. Graph of Forecasting calculation results.

Based on figure 1 shows that the composite stock price index experienced a significant decline in 2020, when the Covid-19 pandemic began to spread in Indonesia from March to April. However, this significant decline then began to rise again, namely after May the composite stock price index began to show an increase and this was accompanied by a new government policy to implement a new standard so as to provide opportunities for companies to resume their operational activities based on the covid-19 protocol policy in the new normal era.

The new normal policy set is different from normal conditions such as before the pandemic, so that the company's performance after the new normal policy is implemented is also still under normal conditions. Figure- 1 is shown by the increase in the composite stock price index after the new normal policy, the value is still half of the value of the composite stock price index before the Covid-19 pandemic. This increase shows that the new normal policy has quite an effect on the increase in the composite stock price index because the company can carry out its operational activities better than before during the government policy for lockdown and PSBB 
The center moving average shown in Figure-1 shows a movement that is almost similar to the original composite stock price index data so that it shows that the forecasting results are entirely accurate. Based on forecasting calculations using the exponential smoothing method, Figure-1 shows that the forecasting of the composite stock price index for 2021 is close to normal. This supports the statement from the Minister of Finance of the Republic of Indonesia Sri Mulyani stating that the Indonesian economy will improve in 2021 [3].

\section{CONCLUSION}

The calculation results of forecasting the combined stock price index show that the stock price index in 2021 will increase to its value as it did before the Covid-19 pandemic. This is because the support of the new standard policy that has been implemented by the Indonesian government can provide opportunities for companies to carry out operational activities even though the covid-19 pandemic is not over. Investors can use forecasting information This composite stock price index to determine the action of selling or buying shares because the composite stock price index reflects the performance conditions of all companies listed on the Indonesia Stock Exchange and shows the country's economic needs.

Suggestions for further research are to be able to predict the composite stock price index of each sector, namely whether it had shown normal conditions like before the Covid-19 pandemic occurred.

\section{REFERENCES}

[1] D. Junaedi and F. Salistia, "Dampak Pandemi Covid-19 terhadap Pasar Modal di Indonesia: Studi Kasus Indeks Saham Komposit (ISHG),” Al-
Kharaj: Jurnal Ekonomi, Keuangan \& Bisnis Syariah, vol. 2, no. 2, pp. 109-131, 2020.

[2] S. Tesa, "Pengaruh Suku Bunga Internasional (LIBOR), Nilai Tukar Rupiah/ US\$ dan Inflasi terhadap Indeks Harga Saham Gabungan di Bursa Efek Indonesia Tahun 2000-2010," Economics Development Analysis Journal, vol. 1, no. 1, pp. 1-13, 2012.

[3] D. Tambunan, "Investasi Saham di Masa Pandemi Covid-19," Widya CIpta: Jurnal Sekretari dan Manajemen, vol. 4, no. 2, pp. 117-123, 2020.

[4] I.C. Pradhypta, D. Iskandar, and R.C. Tarumingkeng, "Analisis FaktorFaktor yang mempengaruhi Indeks Harga Saham Gabungan di Bursa Efek Indonesia," Jurnal Manajemen Bisnis, vol. 13, no. 1, pp. 43-56, 2018 .

[5] R. Susanti and A.R. Adji, "Analisis Peramalan IHSG dengan Time Series Modeling Arima,” Jurnal Manajemen Kewirausahaan, vol. 17, no. 1, pp. 97-106, 2020.

[6] I.L.P. Navalina, N.P. Riwajanti, S. Sulistyono, and L. Djajanto, "Forecasting Produksi Perikanan Laut yang Dijual di TPI (Ton) dengan Metode Single Exponential Smoothing," Media Mahardika, vol. 18, no. 2,2020 .

[7] N. Sulthan, N. Eltivia, and N.I. Riwajanti, "Implementasi Metode Exponential Smoothing untuk Peramalan Kedatangan Wisatawan Mancanegara pada Pulau Bali," Media Mahardika, vol. 18, no. 2, pp. 171-178, 2020.

[8] U. Sa'adah and Suhadak, "Pengaruh Makroekonomi terhadap kinerja Indeks Harga Saham Gabungan (IHSG) dan Governtment Bonds (Studi pada Negara Indonesia Tahun 2015-2017)," Jurnal Administrasi Bisnis (JAB), vol. 73, no. 1, pp. 151-159, 2019.

[9] S. Wardah and Iskandar, "Analisis Peramalan Penjualan Produk Keripik Pisang Kemasan Bungkus,” Jurnal Teknik Industri, vol. 11, no. 3, pp. 135-142, 2016.

[10] N.L.W.S.R. Ginantra and I.B.G. Anandita, "Penerapan Metode Single Exponential Smoothing dalam Peramalan Penjualan Barang," Jurnal Sains \& Informatika (J-Sakti), vol. 3, no. 2, pp. 433-441, 2019.

[11] I.F. Rahmawati, N. Eltivia, and K. Susilowati, "Peramalan Kedatangan Wisatawan Mancanegara Indonesia : Metode Holt's Winter Exponential Smoothing," Media Mahardika, vol. 18, no. 2, pp. 233-241, 2020.

[12] Y.W. Lee, K.G. Tay, and Y.Y. Choy, "Forecasting Electricity Consumption Using Time Series Model," International Journal of Engineering \& Technology, vol. 7, pp. 218-223, 2018. 